MIDPI

sciforum

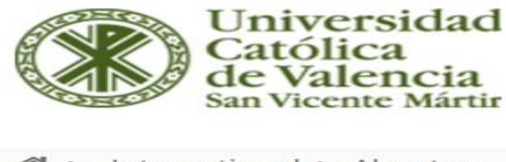

A $>$ International > About us

\section{International}

\section{IWIMSM-03: Iberoamerican Workshop on} Model. and Simulation Methods, Valencia, Spain, 2019

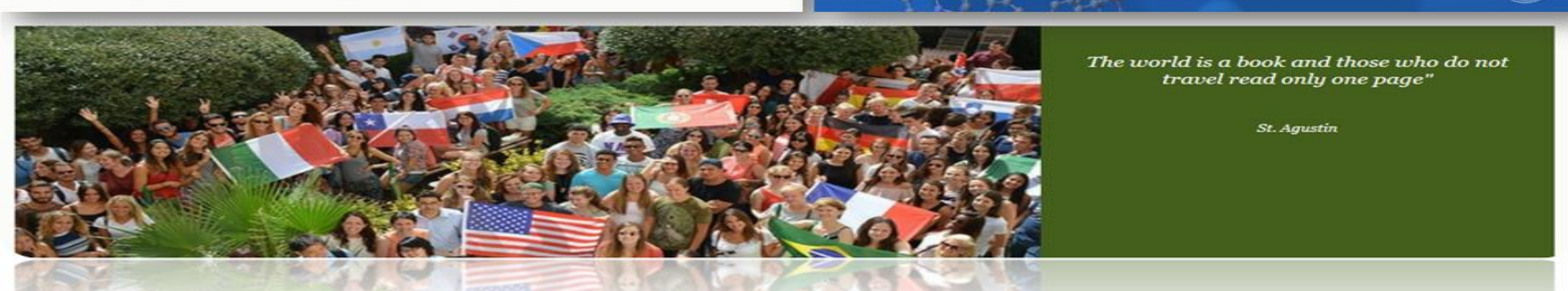

\title{
Discriminant Equations for the Search of New Antibacterial Drugs
}

Jose I. Bueso-Bordils ${ }^{a}$, Pedro A. Alemán-López ${ }^{a}$, Beatriz Suay-Garcia ${ }^{b}$, Rafael MartínAlgarra ${ }^{a}$, Maria J. Duart ${ }^{a}$, Antonio Falcób, Gerardo M. Antón-Fos ${ }^{a}$.

${ }^{a}$ Departamento de Farmacia, Instituto de Ciencias Biomédicas, Facultad de Ciencias de la Salud.

Universidad Cardenal Herrera-CEU, Valencia, España

${ }^{b}$ ESI International Chair@CEU-UCH. Departamento de Matemáticas, Física y Ciencias

Tecnológicas. Universidad Cardenal Herrera-CEU, Valencia, España

\begin{tabular}{|c|c|}
\hline Graphical Abstract & Abstract \\
\hline $\begin{array}{l}\text { Quinolones and } \\
\text { structurally related } \\
\text { compounds }\end{array}$ & $\begin{array}{l}\text { In this study, molecular topology was used to develop several } \\
\text { discriminant equations capable of classifying compounds according to }\end{array}$ \\
\hline Non Antibactel & their antibacterial activity. \\
\hline & Topological indices were used as structural descriptors and their \\
\hline & $\begin{array}{l}\text { relation to antibacterial activity was determined by applying linear } \\
\text { discriminant analysis (LDA) on a group of quinolones and quinolone- }\end{array}$ \\
\hline Molecular Topology & like compounds. \\
\hline Linear Discriminant Analysis & Four extra equations were constructed, named DF3, DF4, DF5 and \\
\hline & $\begin{array}{l}\text { DF6 (DF1 and DF2 were built in a previous study), all with good } \\
\text { statistical parameters such as Fisher-Snedecor } F(>25 \text { in all cases), }\end{array}$ \\
\hline $\begin{array}{l}\text { Discriminant equations } \\
\text { DF3, DF4, } \\
\text { DF5 and DF6 }\end{array}$ & $\begin{array}{l}\text { Wilk's lambda }(<0.36 \text { in all cases }) \text { and percentage of correct } \\
\text { classification }(>80 \% \text { in all cases }) \text {, which allows a reliable }\end{array}$ \\
\hline$\sqrt{4}$ & $\begin{array}{l}\text { extrapolation prediction of antibacterial activity in any organic } \\
\text { compound. }\end{array}$ \\
\hline $\begin{array}{c}\text { Statistical \& Efficiency } \\
\text { Validation }\end{array}$ & $\begin{array}{l}\text { The results obtained clearly reveal the high efficiency of combining } \\
\text { molecular topology with LDA for the prediction of antibacterial activity. }\end{array}$ \\
\hline
\end{tabular}




\section{References (mandatory)}

. Bueso-Bordils JI, Aleman PA, Lahuerta Zamora L, Martin-Algarra R, Duart MJ, Anton-Fos GM. Topological model for the search of new antibacterial drugs. 158 theoretical candidates. Curr. Comput. Aided Drug Des., 2015; 11(4): 336-345.

. Kier LB, Hall LH. The meaning of molecular connectivity: a bimolecular accessibility model. Croat. Chem. Acta, 2003; 75(2): 371-382.

. García-Doménech R, Gálvez J, de Julián-Ortiz JV, Pogliani L. Some new trends in chemical graph theory. Chem. Rev., 2008; 108(3): 1127-69. 